\title{
Impact of Entrepreneurial Education on Entrepreneurial Intentions of Pakistani Students
}

\author{
Altaf Hussain (Corresponding author) \\ $\mathrm{PhD}$ Scholar, CEDI University of Uttara Malaysia \\ Lecturer, Sukkur Institute of Business Administration, Pakistan \\ Email: altaf@iba-suk.edu.pk \\ Dr. Norashidah \\ Deputy Director, CEDI University of Uttara Malaysia
}

Doi:10.5296/ jebi.v2i1.7534 URL: http://dx.doi.org/10.5296/ jebi.v2i1.7534

\begin{abstract}
Why an individual prefer to become an entrepreneur and what factor motivated his intentions for becoming an entrepreneur is considered important question in entrepreneurship research. Entrepreneurial education is considered an important variable which effect on entrepreneurial intentions. However, empirical research results on entrepreneurial education and entrepreneurial intention yielded mixed results. To investigate further this question from developing countries perspective, this paper looks at the role of entrepreneurial education in developing the entrepreneurial intentions for becoming entrepreneur. The sample for this study composed of final year business students from Pakistan. The result of this study supports the entrepreneurial intentions model based on the theory of planned behavior. The results further suggested significant influence of entrepreneurial education on entrepreneurial intentions of the students. Moreover, this study results also showed that theoretical knowledge of entrepreneurship (know-what) and knowledge of social network development (know-who) component are vital for imparting entrepreneurial education.
\end{abstract}

Keywords: Entrepreneurial Intentions, Entrepreneurial Education, Know-What, Know-Why. 


\section{Introduction}

In developing countries, entrepreneurship is considered vital for enhancing employment opportunities. Such impact of entrepreneurship is also evident from territories which reported declines in the unemployment levels because they have the higher level of increase in entrepreneurial initiative indexes (Audretsch, 2002). In spite of such global recognition, entrepreneurship remains limited in Pakistan. This happens due to limited attention of policy maker and government toward entrepreneurship in the past, and lower level of growth in key indicators for starting new business of Pakistan's, limited economy to absorb shocks (Haque, 2007). Such attitude towards entrepreneurship in the past have affected the entrepreneurial attitude and intentions of people in Pakistanwhich is just 23\% as per Global Entrepreneurship Monitor (GEM) report on Pakistan (Sarfraz \& Qureshi, 2011). While the report of GUESS (2011) has ranked Pakistan at lowest on student's intention to become an entrepreneur by starting their own business after completing the study.

Entrepreneurship researchers have identified various determinants of individual entrepreneurial intentions. Entrepreneurship education has been recognized as one of the important determinant of entrepreneurial intentions. Various studies like Galloway and Brown (2002); Fayolle, Gailly and Lassas-Clerc (2006); Potter (2008); Henderson and Robertson (2000); Zhang, Duysters, and Cloodt (2013) empirically demonstrated the entrepreneurial education as an important determinant of entrepreneurial intentions.

Although the importance of entrepreneurship education had been recognized in the literature, but limited empirical studies have been conducted to analyze the impact on entrepreneurial intention separately from general education (Peterman \& Kennedy, 2003). As mentioned by Byabashaija and Katono (2011, p. 129): "The effect of general education has been explored but only a few studies have looked at entrepreneurial education, particularly at university and tertiary institution level." According to Byabashaija and Katono (2011), the effect of entrepreneurship education on entrepreneurial intention is limited and still undergoing empirical testing. In their study Zhang et al. (2013) concluded that despite the importance of entrepreneurship education it's unusual to observe that few studies have been conducted to see the impact of entrepreneurship education on intention.

In consistent with the study of Zhang et al. (2013), a survey of the literature on entrepreneurial intentions research has identified limited studies conducted at tertiary institutes in Pakistan. Only few studies have been conducted to analyze the effect of entrepreneurship education on entrepreneurship intentions of individual in Pakistan. While there is very limited research demonstrated empirically the impact of different component taught during entrepreneurial education course on the entrepreneurial education and intentions. The purpose of this study is to analyze the impact of entrepreneurship education on intentions of the students studying in higher education institutes in Pakistan .This study will also analyze the significance of different component of entrepreneurship education program in imparting entrepreneurship education at tertiary level. 


\section{Theoretical Framework}

According to Shane (2003) entrepreneurship process consist of capability to identify opportunity, collect resources, organize them and adapt strategy so that opportunity can be exploited. The knowledge, skills and information he obtained through education will likely improve the expected returns for exploiting the opportunity. Entrepreneurship education not only improves knowledge skill and information which needed to pursue an opportunity but also equip individual with analytical ability and knowledge of entrepreneurial process which improve the entrepreneurial judgment (McMullen \& Shepherd 2006).

The study of European Commission (2006) reported that entrepreneurship specific education encourage students in accumulating entrepreneurial intentions which results in creation and supply of new firms by the students. Researchers agreed that the influence of "push" and "pull" while studying entrepreneurship may determine their entrepreneurial career path (Matlay \& Storey, 2003). Galloway and Brown (2002); Henderson and Robertson (2000) in their studies also showed that linkages between entrepreneurial education and entrepreneurial activity of students. While the study of the Potter (2008) highlighted the function of entrepreneurship education is vital in enhancing the entrepreneurship attitudes of individuals at tertiary level of education. Therefore, entrepreneurship education initiatives at university level are considered vital for increasing potential entrepreneurs supply by making more students conscious and interested choosing entrepreneurship as a career option.

Accordingly entrepreneurship education in the form of courses is correlated to entrepreneurial intentions for three reasons. First, entrepreneurship education helps the students to learn and identify new business opportunities. Such knowledge leads to enhance the number and innovativeness of opportunities which are linked with the technology (Shepherd \& DeTienne, 2005). Learning important entrepreneurial skills and competencies will lead to perceive new feasible venture by students, thus affect PBC (Krueger et al., 2000; Zhao et al., 2005). Second, research found positive association between social desirability and entrepreneurship career intention (Tkachev \& Kolvereid, 1999). While the important role of education is counted in socializing individuals into entrepreneurial careers (Krueger \& Brazeal,1994) which can form attitude toward behaviour and social norms. Third, through entrepreneurship courses one get knowledge about starting new business venture in a better and faster way the that result in more value from the identical opportunity (Zhao et al., 2005; Davidsson \& Honig, 2003).

It is also argued in the studies that learning important entrepreneurial skills and competencies will lead to perceive new feasible venture by students, thus affect Perceived Behavioural Control (PBC) (Krueger et al., 2000; Zhao et al., 2005). Results of different empirical studies have confirmed that PBC, attitude and social norms are the major factors for explaining entrepreneurial intention (Autio et al. 2001; Kolvereid 1996; Krueger and Carsrud, 1993; Liñán and Chen 2009; Liñán et al. 2011). Due to this reason, it is argued that for motivating entrepreneurship intention through entrepreneurship education should consider those elements. In their study Zhang et al. (2013) not only empirically demonstrated the impact of entrepreneurship education on entrepreneurship intention but also showed that 
entrepreneurship education directly effect on entrepreneurship intentions. This conclusion is beyond the prevailing perspective which assume that entrepreneurship education indirectly effect on entrepreneurship intentions. This study also suggested for further study on the relationship between entrepreneurship education and intentions especially from developing countries context because there is little research from that perspective.

In their study Oosterbeek et al. (2010) concluded that the negative impact of entrepreneurship education on entrepreneurship intentions. In this study they also reported entrepreneurship education impact on entrepreneurial skills/ traits was significantly zero or negative. They argued that such results may be linked to the fact that during entrepreneurship education students have acquired "realistic perspectives" about themselves and what is required to be an entrepreneur. While study of Graevenitz, Harhoff, and Weber (2010) found the effect of entrepreneurship education on entrepreneurial intentions decreased to certain extent, even though the entrepreneurship course have significantly positive impact on students' entrepreneurial skills. Lorz, Müller, and Volery (2011) in the Meta analysis of impact studies and applied methodologies of entrepreneurship education suggested mainly three reasons for such confusing results on the impact of entrepreneurship education on intentions: first in method used, for example small sample and cross section design, lack of ex-ante/ex-post and control group; second variety of different entrepreneurship programs as independent variable and third variation in participant levels.

Nevertheless; still there is limited agreement on the variables which are the basis of individual decision of starting a new venture. Because majority studies on entrepreneurial education and intentions focused on general impact of entrepreneurial education on intention and measured the entrepreneurship intention before or after entrepreneurship course or program (Lo, 2011). This may be because as (Neck, Greene, Branson, \& Ash, 2011 p:66) said "Our purpose was to acknowledge that we teach in several different worlds. Many teach in more than one world, but the environment for entrepreneurship is changing whereas education for entrepreneurship is not".

This suggests need of more empirical studies to understand the various factors impact on entrepreneurial intentions when individual get entrepreneurship education. The university education of entrepreneurship has initially major focus on the know-what for imparting basic definitions and concepts of business knowledge, management and entrepreneurship (Johannisson, 1991) which describe the theoretical aspect of entrepreneurship. More over the Know-who component enhance students networking at societal level by developing interaction with different entrepreneurial people, such as business man, entrepreneurial role models, professors, and classmates (Johannisson,1991).

Therefore, this study has developed the following model to analyze the impact of university entrepreneurship education on intentions of becoming entrepreneur. 


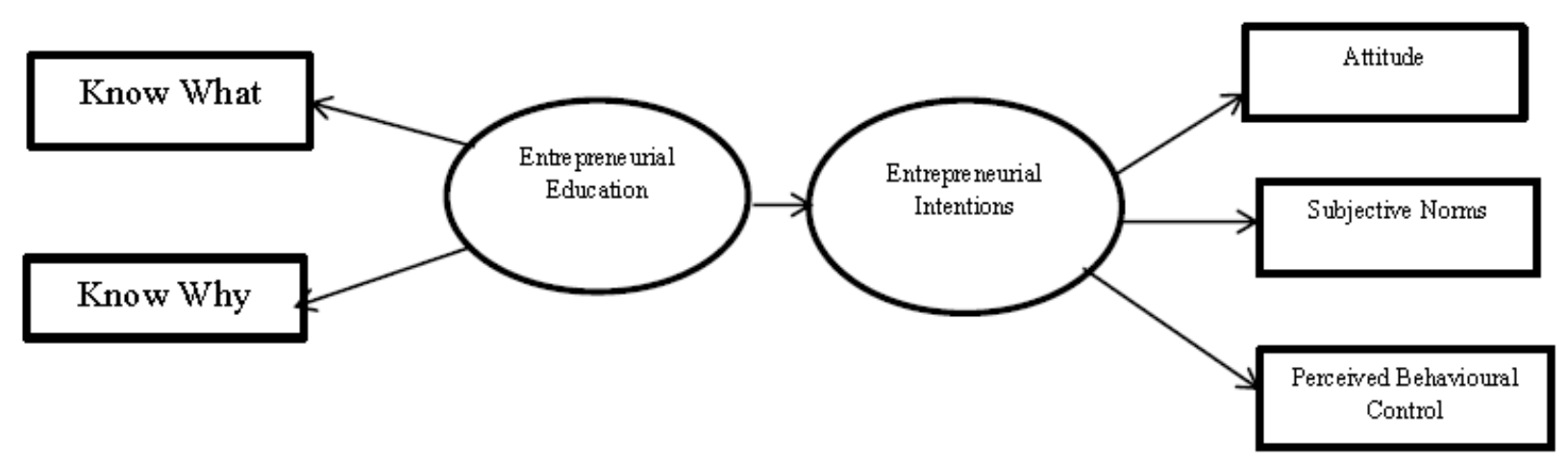

Figure 1

Research Model

\section{Hypothesis}

H1: Attitude towards entrepreneurship effects on the students' intentions to become an entrepreneur.

H2: Subjective norms towards entrepreneurship effect on students' entrepreneurship intentions.

H3: Perceived behavioural control towards entrepreneurship effect on students' entrepreneurship intentions.

H4: Attitude, subjective norm and the perceived behavioural control of student toward entrepreneurship effect on the students' entrepreneurship intentions

H5: Entrepreneurship education effect on intentions of students towards entrepreneurship.

\section{Research Methodology}

This study was conducted on the final year undergraduate and graduate students of business studies studying in various public and private HEIs/ universities in Sindh, Pakistan. Data was collected through self-administered survey method based on the questionnaire which is adapted from EIQ of (Linan \&Chen, 2009) on entrepreneurial intentions and entrepreneurial education questioner of (Lo, C. T., \& Sun, H. Y. 2008). A sample of 499 students from 9 HEIs of Sindh was used for the study collected from March2014 to May2014.

\section{Data Analysis and Findings}

This study applied structural Equation Modeling (SEM) Path analysis, using AMOS 18.0 to test the inter-relationship between entrepreneurial intentions and entrepreneurial education.

This study used the factor analysis to measure the validity. Kaiser-Meyer-Olkin measure of sample adequacy was .926 and Bartlett's test of Sphericity was highly significant $(\mathrm{p}<.001)$. These results suggested that data is suitable for conducting factor analysis. Six factors that has cumulative loading of $67.98 \%$ with factor loading values ranging from .54 to .91 has been extracted. Further, from the data four items which are KWO1, KWO2, Attitude5 and PBC2 


\section{Macrothink}

have been removed due to lower than .35 factors loading. While all other items have loaded more than .50 on each factor The tests of reliability showed that all the factor have Cronbach Alpha from (.76) to (.91). As shown in the table no2. These results suggest that data is reliable and valid for further analysis on SEM.

Table1: Reliability Statistics of Different Variables

\begin{tabular}{lcc}
\hline Variable & Cronbach's Alpha & No of Items \\
\hline Attitude & .843 & 5 \\
Subjective Norms & .767 & 3 \\
& & \\
Perceived Behavioral & .827 & 6 \\
Control & & \\
Entrepreneurial & .910 & 6 \\
Intentions & .914 & 5 \\
Know What & .848 & 5 \\
& \\
Know Who & & \\
\end{tabular}

The structural model for the relationship between entrepreneurial intentions and entrepreneurial education has a degree of freedom 263 for the sample of 499 students as shown in the table blow. The first step for analyzing the structural model is to look at the model fit indexes (Hoyle, 1995). The Chi-square $(\chi 2)$ value which "assesses the magnitude of the discrepancy between the sample and fitted co-variances matrices" (Hu \& Bentler, 1999: 2) has the value of 586.593 and is significant with $(\mathrm{p}<.000)$. A good model fit would provide an insignificant result at the 0.05 threshold. As this assumption is sensitive to sample size if it holds does not mean that the model fits the data, thus need to consider other indices (Bollen \& Long, 1993).

The value of Chi-square is sensitive to the sample size therefore CMIN/df value that is $\chi 2 / \mathrm{df}$ was used to adjust the effect of sample size. The values for $\chi 2 / \mathrm{df}$ are 2.37 which is below the suggested cut off value of 3 (Tabachnick \& Fidell, 2007). Therefore, after adjusting the sample size, $\chi 2 / \mathrm{d}$ specified that the model is a good fit.

The model incremental fit indices like (GFI, NFI, CFI and TLI) which are not using the chi-square are employed in the model. GFI assess the sample correlation matrix variability proportion explained by the model. The value of GFI in the model is (.91) which is above 
(.90) threshold value this suggests that the model is a good fit. The statistics results of CFI compare the default model with the null model. CFI value of (.94) which is above the (.90) value suggests that the model is a good fit. While the NFI, the compare target model with the baseline model. The NFI value of (.91) which suggests that model is a good fit. The RMSEA communicates about "how model with unknown but optimally chosen parameter estimates would fit the population's covariance matrix" (Byrne, 1998). The RMSEA value of (.050) which is below the cut-off value of (.06) (Hu and Bentler, 1999) suggest that the model is a good fit. The TLI compare default model and the null model has value of .95 which is above the .90 suggest that the model is a good fit. Considering the different indexes, we conclude that entrepreneurial education and entrepreneurial intentions model is a good fit with the data.

Table 2: Model Fit Indices

\begin{tabular}{lrrrrrrrr}
\hline $\begin{array}{l}\text { Sample } \\
\text { Size }\end{array}$ & $\mathrm{X}^{2}$ & Df & CMIN/X & RMSEA & NFI & CFI & GFI & TLI \\
\hline 499 & 586.593 & 263 & 2.230 & .05 & .92 & .94 & .91 & .95 \\
\hline
\end{tabular}

After that the next step is to assess the hypothesized models for assessing that the parameter estimates are adequate(Hoyle, 1995).The MLE (Maximum Likelihood Estimation) method was used to estimate the path parameters of the entrepreneurial education and intention model. The results of MLEs of the parameters are given in the table 4

Table 3: Hypothesis testing Results

\begin{tabular}{lllllr}
\hline Hypothesis & $\begin{array}{l}\text { Parameter } \\
\text { estimates }\end{array}$ & S.E. & C.R. & P & Result \\
\hline Attitude $\rightarrow$ E.I & .554 & .071 & 7.51 & $* * *$ & Accepted \\
S.N $\rightarrow$ E.I & .577 & .064 & 10.34 & $* * *$ & Accepted \\
PBC $\rightarrow$ E.I & .611 & .056 & 8.26 & $* * *$ & Accepted \\
EE $\rightarrow$ E.I & .519 & .062 & 4.66 & $* * *$ & Accepted \\
\hline
\end{tabular}

Note: ${ }^{* * * *}$ indicate significant at .001

The path analysis suggests that the impact of Attitude $(0.554, \mathrm{P}<.001)$, subjective norms $(0$. $577, \mathrm{P}<.001)$ and perceived behavioural control $(0.611, \mathrm{P}<.001)$. This result suggests that attitude, subjective norms and perceived behavioural control were significantly related entrepreneurial intentions as antecedents. More ever the path analysis result also for Know-what $(0.718, \mathrm{P}<.001)$ and know-why $(.989, \mathrm{P}<.001)$. This shows that the know-what and know-why component has very high and significant impact on entrepreneurial education. 
While the entrepreneurial Education has also had a significant impact on entrepreneurial intentions $(0.519, \mathrm{P}<.001)$.

\section{Discussion and Conclusion}

Increasing importance of entrepreneurship in developing and developed countries highlighted in the literature because of its impact on socio economic effectiveness, innovation and job creation (Shane \& Venkataraman, 2000). Although with such a high impact has been empirically demonstrated but very limited studies have been conducted to analyze the impact of entrepreneurial education. Especially the impact of entrepreneurial education on intentions (Zhang et al., 2013). In the literature, limited studies have been conducted to analyze the impact of entrepreneurial education on intentions from the perspective of developing countries.

In an effort to reduce the gap, this study has been conducted to see the impact of entrepreneurial education on entrepreneurial intentions and to validate the TPB theory to measure the entrepreneurial intentions in Pakistan. The focus for the study was to look at the impact of particular components of entrepreneurship education i-e theoretical knowledge or Know- what and social networking or Know-who.

Result of this study validated the TPB theory by measuring entrepreneurial intentions in Pakistan using the three components of TPB i.e. attitude, subjective norms and PBC. This study also empirically demonstrated the impact of entrepreneurial education on intention along with the impact of the particular component of entrepreneurship education programs on entrepreneurial education. The result of this study also suggests that entrepreneurship can be promoted through entrepreneurial education.

This study also contributes that theoretical knowledge and social network development are the significant contributors of entrepreneurial learning process which results that entrepreneurship education play an important role enhancing the entrepreneurial intentions. This can foster the entrepreneurial spirit through entrepreneurial education and have an effect on the perception for becoming an entrepreneur (Schulte, 2004). Considering such results entrepreneurship education programs should be designed with equal importance to theoretical and developing network component of entrepreneurial education along with other components. Thus, the tertiary level institutes are considered to be the facilitators of an entrepreneurial culture; resulting a strong focus on entrepreneurship education that will be useful in promoting entrepreneurial intentions and culture (Morris et al. 2013). Therefore, it is important for teachers of the entrepreneurship to focus on imparting theoretical knowledge to potential entrepreneurs (Fiet, 2001) and development of social network through entrepreneurship education programs along with other components.

\section{References:}

Ajzen, I. (1991). The theory of planned behavior. Organizational behaviour and human decision processes, 50(2), 179-211.

Ajzen, I. (2001). Nature and operation of attitudes. Annual review of psychology,52(1), 27-58. 


\section{I Macrothink}

Journal of Entrepreneurship and Business Innovation

ISSN 2332-8851

2015, Vol. 2, No. 1

Ajzen, I. (2002). Perceived Behavioural Control, Self-Efficacy, Locus of Control, and the Theory of Planned Behaviour1. Journal of applied social psychology,32(4), 665-683.

Ajzen, I. (2005). Attitudes, personality, and behaviour. McGraw-Hill International.

Ardichvili, A., Cardozo, R., \& Ray, S. (2003). A theory of entrepreneurial opportunity identification and development. Journal of Business Venturing,18(1), 105-123.

Armitage, C. J., \& Conner, M. (2001). Efficacy of the theory of planned behaviour:A meta-analytic review. British journal of social psychology, 40(4), 471-499.

Audretsch, D. B. (Ed.). (2002). Entrepreneurship: determinants and policy in a European-US comparison (Vol. 27). Springer.

Byabashaija, W., \& Katono, I. (2011). The impact of college entrepreneurial education on entrepreneurial attitudes and intention to start a business in Uganda. Journal of Developmental Entrepreneurship, 16(01), 127-144.

Bird, B. (1988). Implementing entrepreneurial ideas: The case for intention.Academy of management Review, 442-453.

Bollen, K. A., \& Long, J. S. (Eds.). (1993). Testing structural equation models(Vol. 154). Sage.

Ciavarella, M. A., Buchholtz, A. K., Riordan, C. M., Gatewood, R. D., \& Stokes, G. S. (2004). The Big Five and venture survival: Is there a linkage?.Journal of Business Venturing, 19(4), 465-483.

European Commission. (2006). Entrepreneurship education in Europe: Fostering entrepreneurial mindsets through education and learning. In Final proceedings of the conference on entrepreneurship education in Oslo.

Economic surevy of Pakistan(2012). Retrieved on April 10, 2014, from http://www.finance.gov.pk/survey_1112.html

Fayolle, A., Gailly, B., \& Lassas-Clerc, N. (2006). Assessing the impact of entrepreneurship education programmes: a new methodology. Journal of European Industrial Training, 30(9), 701-720.

Fayolle, A., \& Gailly, B. (2008). From craft to science: Teaching models and learning processes in entrepreneurship education. Journal of European Industrial Training, 32(7), $569-593$

Fiet, J. O. (2001). The theoretical side of teaching entrepreneurship. Journal of Business Venturing, 16(1), 1-24. Fiet, J. O. (2001). The pedagogical side of entrepreneurship theory. Journal of Business Venturing, 16(2), 101-117.

Fishbein, M., \& Ajzen, I. (1975). Belief, attitude, intention and behaviour: An introduction to theory and research. Reading, Mass.: Addison-Wesle

Gelderen. V, M., Brand, M., van Praag, M., Bodewes, W., Poutsma, E., \& Van Gils, A. (2008). 


\section{Macrothink}

Journal of Entrepreneurship and Business Innovation ISSN 2332-8851 2015, Vol. 2, No. 1

Explaining entrepreneurial intentions by means of the theory of planned behaviour. Career Development International, 13(6), 538-559.

Galloway, L., \& Brown, W. (2002). Entrepreneurship education at university: a driver in the creation of high growth firms?. Education+ Training, 44(8/9), 398-405.

Godsey, M. L. (2006). Gaining entrepreneurial perspective: The impact of venture creation role models on high school career intention.

Graevenitz , Von, G., Harhoff, D., \& Weber, R. (2010). The effects of entrepreneurship education. Journal of Economic Behavior \& Organization,76(1), 90-112.

Haque, N. U. (2007). Entrepreneurship in Pakistan (No. 2007: 29). Pakistan Institute of Development Economics.

Hoyle, E., \& John, P. D. (1995). Professional knowledge and professional practice. London: Cassell.

Hu, L. T., \& Bentler, P. M. (1999). Cutoff criteria for fit indexes in covariance structure analysis: Conventional criteria versus new alternatives. Structural Equation Modeling: A Multidisciplinary Journal, 6(1), 1-55.

Hyder, A., Azhar, A., Javaid, A., \& Rehman, M. (2011). Entrepreneurial Intentions among Business Students in Pakistan. Journal of Business Systems, Governance and Ethics, 5(2).

Kocoglu, M., \& Hassan, M. U. (2013). Assessing Entrepreneurial Intentions of University Students: A Comparative Study of Two Different Cultures: Turkey and Pakistani. European Journal of Business and Management, 5(13), 243-252.

Kolvereid, L. (1996). Prediction of employment status choice intentions.WORKING PAPER SERIES-HENLEY MANAGEMENT COLLEGE HWP.

Johannisson, B. (1991). University training for entrepreneurship: Swedish approaches. Entrepreneurship \& Regional Development, 3(1), 67-82.

Krueger, N. F., Reilly, M. D., \& Carsrud, A. L. (2000). Entrepreneurial intentions: A competing models approach. Journal of Business Venturing,15(5/6), 411-432.

Liñán, F., Rodríguez-Cohard, J. C., \& Rueda-Cantuche, J. M. (2011). Factors affecting entrepreneurial intention levels: a role for education. International Entrepreneurship and Management Journal, 7(2), 195-218.

Liñán, F., \& Chen, Y. W. (2009). Development and Cross-Cultural application of a specific instrument to measure entrepreneurial intentions. Entrepreneurship Theory and Practice, 33(3), 593-617

Lo, C. T. (2011). The impact of entrepreneurship education on entrepreneurial intention of engineering students (Unpublished doctoral thesis) Cityu University of Hong Kong

Lorz, M., Müller, S., \& Volery, T. (2011). Entrepreneurship Education: A Meta Analysis of Impact Studies and Applied Methodologies. In Conference Paper, FGF G-Forum 2011. 
McMullen, J. S., \& Shepherd, D. A. (2006). Entrepreneurial action and the role of uncertainty in the theory of the entrepreneur. Academy of Management Review, 31(1), 132-152.

Menzies, T. V., \& Paradi, J. C. (2003). Entrepreneurship education and engineering students-Career path and business performance. The International Journal of Entrepreneurship and Innovation, 4(2), 121-132.

Morris, M. H., Webb, J. W., Fu, J., \& Singhal, S. (2013). A Competency-Based Perspective on Entrepreneurship Education: Conceptual and Empirical Insights.Journal of Small Business Management, 51(3), 352-369.

Obschonka, M., Silbereisen, R. K., \& Schmitt-Rodermund, E. (2012). Explaining entrepreneurial behaviour: Dispositional personality traits, growth of personal entrepreneurial resources, and business idea generation. The Career Development Quarterly, 60(2), 178-190

Oosterbeek, H., van Praag, M., \& Ijsselstein, A. (2010). The impact of entrepreneurship education on entrepreneurship skills and motivation. European economic review, 54(3), 442-454.

Pittaway, L., \& Cope, J. (2007). Entrepreneurship Education A Systematic Review of the Evidence. International Small Business Journal, 25(5), 479-510.

Peterman, N. E., \& Kennedy, J. (2003). Enterprise education: Influencing students' perceptions of entrepreneurship. Entrepreneurship theory and practice, 28(2), 129-144.

Sarfraz, M., \& Quresh, S. (2013). The Global Entrepreneurship Monitor Pakistan Report. 2011. GEM Pakistan 2011 Report.

Shane, S., \& Venkataraman, S. (2000). The promise of entrepreneurship as a field of research. Academy of management review, 25(1), 217-226.

Sieger,P. , Fueglistaller,U. , Zellweger,T.. Global University Entrepreneurial Spirit Students' Survey 2011 International Report. Retrieved on October 11, 2013, from http://www.guesssurvey.org/PDF/2011/GUESSS_INT_2011_FINAL.pdf

Tabachnick, B. G., \& Fidell, L. S. (2007). Experimental designs using ANOVA. Thomson/Brooks/Cole.

The New Growth Framework Pakistan(2011), Retrieved on April 16, 2013, from http://www.pc.gov.pk/hot\%20links/growth_document_english_version.pdf

Tkachev, A., \& Kolvereid, L. (1999). Self-employment intentions among Russian students. Entrepreneurship \& Regional Development, 11(3), 269-280.

Zhang, Y., Duysters, G., \& Cloodt, M. (2013). The role of entrepreneurship education as a predictor of university students' entrepreneurial intention. International Entrepreneurship and Management Journal.

Zhao, H., Seibert, S. E., \& Hills, G. E. (2005). The mediating role of self-efficacy in the development of entrepreneurial intentions. Journal of applied psychology, 90(6), 1265. 